\title{
Regenerasi Tunas Suweg (Amorphophallus paeoniifolius (Dennst.) Nicolson) pada Berbagai Konsentrasi BAP dan NAA dengan Kondisi Penyimpanan Terang dan Gelap
}

\author{
Regeneration of Suweg (Amorphophallus paeoniifolius (Dennst.) Nicolson) \\ Grown in Various Concentrations of BAP and NAA under Light and Dark \\ Storage Conditions
}

\author{
Author(s): Yupi Isnaini ${ }^{(1) * ;}$ Yeyen Novitasari ${ }^{(1)}$ \\ (1) Pusat Penelitian Konservasi Tumbuhan dan Kebun Raya, LIPI \\ * Corresponding author: yupi002@lipi.go.id
}

\begin{abstract}
ABSTRAK
Amorphopallus paeoniifolius atau suweg merupakan salah satu jenis dari suku Araceae yang umbinya berpotensi untuk dikembangkan sebagai alternatif pangan karena memiliki kandungan gizi yang baik dan indeks glikemik yang rendah. Namun, perbanyakan suweg terkendala dalam ketersediaan bibitnya sehingga dibutuhkan alternatif perbanyakan, salah satunya dengan teknik kultur jaringan. Penelitian ini bertujuan untuk mendapatkan kombinasi media, jenis eksplan dan kondisi kultur yang optimal untuk perbanyakan suweg secara in vitro. Penelitian dilakukan dengan dua percobaan. Percobaan pertama yaitu regenerasi tunas dari eksplan tangkai daun yang ditanam pada media Murashige dan Skoog (MS) yang ditambahkan dengan BAP (0, 1 , 2 , dan $4 \mathrm{mg} / \mathrm{l}$ ) dan NAA (0 dan $0,5 \mathrm{mg} / \mathrm{l})$. Percobaan kedua yaitu regenerasi tunas dari eksplan tangkai daun dan kalus pada kondisi gelap dan terang. Hasil penelitian menunjukkan bahwa media MS dengan penambahan $2 \mathrm{mg} / \mathrm{l} \mathrm{BAP}$ dan 0,5 mg/l NAA merupakan media yang paling baik bagi eksplan tangkai daun dalam pembentukan kalus, tunas dan akar yang ditandai dengan jumlah masing-masing adalah $75 \%, 50 \%$ dan 56,67\%. Selanjutnya, eksplan berupa kalus lebih mudah memberikan respon membentuk tunas dan akar dibandingkan dengan tangkai daun, baik pada kondisi ruang penyimpanan gelap maupun terang.
\end{abstract}

\section{Kata Kunci:}

Amorphophallus paeoniifolius;

Kultur jaringan;

Pangan

alternatif;

Suweg;

\section{Keywords:}

Alternative

food;

Amorphophallus paeoniifolius;

In vitro culture;

Suweg,

\section{ABSTRACT}

Amorphophallus paeoniifolius or suweg is one of the Araceae families whose tubers are the potential to be developed as alternative foods that contain good nutrition and low glycemic index. However, the propagation of the suweg is constrained in the availability of seedlings so that the alternative propagation is needed, one of which is by tissue culture techniques. This study aims to obtain the optimal combination of media, types of explants, and culture conditions for in vitro propagation of suweg. This research was conducted with two experiments. The first experiment was the regeneration of shoots from petiole explants cultured on Murashige and Skoog (MS) media added with BAP (0, $1,2$, and $4 \mathrm{mg} / \mathrm{l})$ and $N A A(0$ and $0,5 \mathrm{mg} / \mathrm{l})$. The second experiment was the regeneration of shoots from petiole and callus explants in dark and light conditions. The results showed that MS media with the addition of $2 \mathrm{mg} / \mathrm{l} \mathrm{BAP}$ and $0,5 \mathrm{mg} / \mathrm{l} \mathrm{NAA}$ were the best media in the formation of callus, shoot, and roots from petiole explants $(75 \%, 50 \%$, $56,67 \%$, respectively). Besides that, the best response was demonstrated by callus compared to petiole in developing more callus, shoot, and root in the dark or light conditions. 


\section{PENDAHULUAN}

Amorphophallus paeoniifolius yang dikenal dengan nama lokal suweg di Pulau Jawa, merupakan salah satu jenis dari suku Araceae (talas-talasan) yang umbinya berpotensi untuk dikembangkan sebagai bahan pangan karena memiliki kandungan gizi yang cukup baik. Umbi suweg ini secara turun temurun telah digunakan sebagai makanan pokok di berbagai daerah dengan cara pemanfaatan yang berbeda (Santosa \& Sugiyama, 2016). Sebelumnya, suweg hanya dilaporkan sebagai sumber pati dan protein seperti kebanyakan kerabat talas-talasan lainnya. Hasil penelitian (Richana \& Sunarti, 2004) mengindikasikan bahwa suweg dan gembili mempunyai prospek untuk dikembangkan sebagai produk tepung umbi maupun tepung pati. Selanjutnya suweg juga diketahui mempunyai potensi untuk mencegah beberapa penyakit degeneratif, termasuk penyakit jantung koroner, melalui mekanisme penurunan kolesterol dalam darah. Hal ini terkait dengan kadar seratnya yang cukup tinggi dan kemampuannya mengikat kolesterol setara dengan oat instan (Faridah, 2005). Selain itu, umbi suweg juga berpotensi sebagai pangan fungsional karena memiliki indeks glikemik kurang dari 55 dan bisa menekan peningkatan kadar gula darah, sehingga sesuai bagi penderita diabetes mellitus (Faridah, 2005; Laksmitawati et al., 2019; Lianah et al., 2018; Nurdyansyah et al., 2019; Singh \& Wadhwa, 2014).

Banyaknya potensi suweg ini memberikan peluang untuk masuk ke dunia industri, tetapi untuk budidaya tanaman ini masih terkendala dalam memperoleh bibit. Sejauh ini, budidaya yang dilakukan oleh sebagian kecil masyarakat di Jawa Barat (Mutaqin et al., 2020; Santosa et al., 2010), Jawa Tengah dan Jawa Timur (Isnaini et al., 2010) hanya dalam jumlah terbatas untuk keperluan sendiri. Umbi suweg diolah menjadi makanan dengan direbus, dibuat kolak, atau dibuat tepung untuk selanjutnya diolah menjadi aneka kue dan makanan di Kabupaten Brebes (Hasanah et al., 2014). Bibit yang digunakan berasal dari tunas umbi atau kulit umbi sisa kupasan dari umbi yang dipanen sebelumnya. Selain itu, perbanyakan suweg lainnya yaitu menggunakan biji, tetapi untuk mendapatkan biji secara alami tidak mudah karena waktu pemasakan antara bunga jantan dan bunga betinanya tidak serentak.

Teknik kultur jaringan bisa menjadi pilihan untuk memperbanyak bibit suweg tanpa ketergantungan pada musim bunga dan buah. Perbanyakan Amorphophallus campanulatus var. hortensis (syn $A$. paeoniifolius) secara in vitro telah dilakukan oleh (Irawati et al., 1986) dari eksplan yang berasal dari mata tunas umbi dan dapat menghasilkan bibit yang normal. Jenis-jenis Amorphophallus lainnya yang telah dipelajari cara perbanyakannya melalui teknik kultur jaringan diantaranya adalah A. albus (Hu et al., 2008; Hu et al., 2006), A. konjac (Zhao, 2012), A. muelleri (Imelda, 2008; Imelda et al., 2007; Prayana et al., 2017), A. oncophyllus (Amphawan et al., 2001), $A$. rivieri (Hu et al., 2005), $A$ paeoniifolius (Kamala \& Makeshkumar, 2014; Kayal et al., 2015) dan A. titanium (Irawati, 2011; Witjaksono et al., 2012).

Aplikasi kultur jaringan untuk memperbanyak bibit Amorphophallus muelleri, A. paeoniifolius, dan A. variabilis juga telah dilakukan dengan menggunakan tulang daun (rachis) sebagai bahan perbanyakan (Isnaini et al., 2012), tetapi jumlah planlet atau bibit yang dihasilkan dari kultur $A$. paeoniifolius masih sangat terbatas. Selain komposisi media dan keberadaan zat pengatur tumbuh yang ditambahkan pada media kultur, jenis dan sumber eksplan serta faktor lingkungan seperti cahaya, suhu, kelembaban dan konsentrasi $\mathrm{CO}_{2}$ merupakan faktor penting yang mempengaruhi pertumbuhan tanaman yang dikultur (Ali et al., 2012; 
Bhatia et al., 2016; Chen, 2004; Irawati, 2000, 2005; Tavakkol Afshari et al., 2011). Penelitian ini bertujuan untuk mendapatkan kombinasi media, jenis eksplan dan kondisi kultur yang optimal untuk perbanyakan suweg ( $A$. paeoniifolius) secara in vitro.

\section{METODOLOGI}

Penelitian

dilakukan di

Laboratorium Kultur Jaringan Pusat Konservasi Tumbuhan Kebun Raya Bogor (sekarang menjadi Pusat Penelitian Konservasi Tumbuhan dan Kebun Raya) Lembaga Ilmu Pengetahuan Indonesia (LIPI). Bahan tanaman yang digunakan dalam penelitian ini adalah tangkai daun dan kalus dari kultur suweg asal Kediri, Jawa Timur (A. paeoniifolius JW 383) hasil penelitian sebelumnya (Isnaini et al., 2012). Penelitian ini terdiri atas 2 percobaan yang dilakukan secara bertahap. Tahap pertama percobaan dilakukan dengan Rancangan Acak Lengkap non Faktorial yaitu variasi konsentrasi zat pengatur tumbuh Benzyl Amino Purine (BAP) dan Naphthalene Acetic Acid (NAA) pada media dasar Murashige \& Skoog (MS) dan tahap kedua penelitian dilakukan dengan Rancangan Acak Lengkap dengan 2 Faktor Perlakuan, yaitu jenis eksplan dan kondisi tempat penyimpanan kultur.

\section{Pelaksanaan Penelitian}

Percobaan 1. Regenerasi Tunas pada Media MS dengan Perlakuan Konsentrasi BAP dan NAA

Media perlakuan dibuat dengan menggunakan bahan media MS yang terdiri dari hara makro, hara mikro dan vitamin dalam bentuk serbuk dalam kemasan dengan komposisi 3,4 g/l, gula pasir $30 \mathrm{~g} / \mathrm{l}$ dan ditambahkan BAP dan NAA sesuai perlakuan berikut:

M0 : Media MS tanpa penambahan BAP dan NAA sebagai kontrol

M1 : Media MS + $1 \mathrm{mg} / \mathrm{l} \mathrm{BAP}$
M2 : Media MS + $1 \mathrm{mg} / \mathrm{l} \mathrm{BAP}+0,5 \mathrm{mg} / \mathrm{l}$ NAA

M3 : Media MS $+2 \mathrm{mg} / \mathrm{l} \mathrm{BAP}$

M4 : Media MS + $2 \mathrm{mg} / \mathrm{l} \mathrm{BAP}+0,5 \mathrm{mg} / \mathrm{l}$ NAA

M5 : Media MS $+4 \mathrm{mg} / \mathrm{l}$ BAP

M6 : Media MS + $4 \mathrm{mg} / \mathrm{l} \mathrm{BAP}+0,5 \mathrm{mg} / \mathrm{l}$ NAA

Derajat keasaman $(\mathrm{pH})$ media diatur menjadi 5,7 $\pm 0,01$ dengan menggunakan $\mathrm{KOH} 1 \mathrm{~N}$ dan HCL 1N. Selanjutnya ditambahkan Gellan Gum sebagai pemadat dan media dimasak sampai mendidih. Media selanjutnya dibagi ke dalam botol kultur dan ditutup rapat, lalu disterilisasi menggunakan autoklaf pada suhu $121^{\circ} \mathrm{C}$ dan tekanan 1 atm selama 15 menit. Media yang telah steril selanjutnya disimpan di ruang media dan siap digunakan.

Tangkai daun dari kultur suweg dipotong-potong sepanjang $\pm 1 \mathrm{~cm}$, kemudian ditanam pada media perlakuan yang telah disiapkan beberapa hari sebelumnya. Penanaman dilakukan secara aseptik di dalam Laminar Air Flow. Setiap perlakuan diulang sebanyak 3 kali, dan setiap ulangan terdiri dari 10 eksplan. Semua kultur tersebut diinkubasikan di ruang kultur dalam kondisi gelap. Subkultur ke media yang sama dilakukan setelah 4 minggu dan kultur dipindahkan ke ruang kultur dengan pencahayaan dari lampu TL 40 watt selama 16 jam/hari.

\section{Percobaan 2. Regenerasi Tunas dari Ekplan Kalus dan Tangkai Daun dengan Kondisi Tempat Penyimpanan Terang dan Gelap}

Eksplan berupa kalus dan tangkai daun dari kultur hasil percobaan 1 setelah 4 bulan perlakuan disubkultur ke Media $\mathrm{MS}+2 \mathrm{mg} / \mathrm{l} \mathrm{BAP}+0,5 \mathrm{mg} / \mathrm{l}$ NAA. Setiap perlakuan diulang 4 kali dan setiap ulangan terdiri dari 5 eksplan. Sebagian kultur yang telah ditanam diinkubasi di ruang kultur dengan kondisi terang menggunakan pencahayaan lampu TL 40 watt selama 16 jam/hari dan sebagian lagi diinkubasi di 
ruang yang sama dengan kondisi gelap di dalam kotak kardus tertutup.

\section{Pengamatan dan analisis data}

Pengamatan dilakukan setiap minggu untuk melihat respon awal dilanjutkan setiap bulan untuk mengetahui perkembangan selanjutnya. Peubah yang diamati meliputi waktu eksplan mulai menunjukkan respon, jumlah eksplan berkalus, jumlah eksplan bertunas dan jumlah tunas, serta jumlah eksplan berakar dan jumlah akar. Suhu dan kelembaban di ruang kultur diukur setiap hari dengan menggunakan termohigrometer. Data kuantitatif hasil pengamatan yang didapatkan dianalisis dengan menggunakan uji sidik ragam (ANOVA) dan dilanjutkan dengan perhitungan Duncan's Multiple Range Test (DMRT) pada taraf 5\% menggunakan perangkat lunak Microsoft Excel dan SAS 9.0.

\section{HASIL DAN PEMBAHASAN}

Berdasarkan hasil pengamatan yang dilakukan, eksplan mulai menunjukkan respon 7 minggu setelah dikulturkan pada hampir semua media yang ditambahkan BAP dan NAA. Respon awal eksplan berupa pembengkakan pada salah satu atau kedua ujung dari potongan tangkai daun suweg tersebut. Pada perkembangan selanjutnya, dari bagian yang membengkak tersebut membesar dan merekah menjadi kalus atau membentuk tonjolan-tonjolan kecil yang kemudian tumbuh menjadi calon tunas atau calon akar. Selain itu, beberapa potongan tangkai daun tidak mengalami perkembangan, tetapi berubah warna dari hijau menjadi coklat kehitaman sampai hitam dan akhirnya mati. Hasil ini tidak berbeda dengan penelitan yang dilakukan Sitorus et al. (2011) yang menyebutkan bahwa kalus dapat terbentuk akibat adanya pelukaan pada eksplan sehingga sel-sel yang rusak memperbaiki diri dan mengalami pembesaran pada dinding sel sehingga terjadi penyerapan air pada media dan mengalami pembengkakan kemudian terjadi pembelahan sel.

Hasil analisis ANOVA menunjukkan konsentrasi BAP yang diberikan hanya berpengaruh nyata pada persentase terbentuknya kalus dan jumlah akar, sedangkan adanya tambahan NAA pada media perlakuan mempengaruhi persentase kalus, tunas, dan akar serta jumlah tunas dan akar yang terbentuk. Interaksi antara BAP dan NAA berpengaruh nyata terhadap semua peubah yang diamati kecuali pada persentase akar (Tabel 1).

Tabel 1. Hasil ANOVA perlakuan BAP dan NAA terhadap peubah yang diamati pada 4 bulan setelah perlakuan

Table 1. ANOVA result of BAP and NAA treatments on observed variables at 4 months after treatment

\begin{tabular}{cccccc}
\hline $\begin{array}{c}\text { Perlakuan } \\
\text { Treatments }\end{array}$ & $\begin{array}{c}\text { Persentase } \\
\text { Kalus } \\
\text { Percentage of } \\
\text { callus }\end{array}$ & $\begin{array}{c}\text { Persentase } \\
\text { tunas } \\
\text { Percentage of } \\
\text { shoots }\end{array}$ & $\begin{array}{c}\text { Persentase } \\
\text { akar } \\
\text { Percentage of } \\
\text { roots }\end{array}$ & $\begin{array}{c}\text { Jumlah tunas } \\
\text { Number of } \\
\text { shoots }\end{array}$ & $\begin{array}{c}\text { Jumlah akar } \\
\text { Number of } \\
\text { roots }\end{array}$ \\
\hline BAP & $*$ & th & th & th & $*$ \\
NAA & $*$ & $*$ & $*$ & $*$ & $*$ \\
Interaksi & $*$ & $*$ & th & $*$ & $*$ \\
BAP*NAA & $*$ & & & & \\
BAP*NAA & & & & & \\
Interaction & & & & & \\
\hline
\end{tabular}

Keterangan: $\mathrm{tn}=$ tidak berbeda nyata, $*=$ berpengaruh nyata pada taraf $5 \%$

Note: $\mathrm{tn}=$ no significant differences, $*=$ significantly different at $5 \%$ significance level 
Secara umum kondisi kultur sampai 4 bulan setelah inkubasi masih didominasi oleh kalus dan beberapa eksplan mulai bertunas dan berakar. Jumlah eksplan yang menghasilkan kalus, tunas, dan akar paling banyak adalah pada media MS dengan penambahan $2 \mathrm{mg} / 1 \mathrm{BAP}$ dan $0,5 \mathrm{mg} / 1$ NAA atau media M4 (Tabel 2). Pada media tersebut, 75\% eksplan membentuk kalus dan $50 \%$ dari kalus tersebut berkembang menghasilkan tunas dengan rata-rata jumlah tunas 1,03. Sebanyak $56,67 \%$ eksplan membentuk akar pada semua media dengan penambahan $0,5 \mathrm{mg} / 1$ NAA dengan jumlah akar berkisar antara 3 $-7,57$.

Tabel 2. Interaksi perlakuan BAP dan NAA terhadap pertumbuhan A. paeoniifolius (JW383) 4 bulan setelah inkubasi pada media dasar MS

Table 2. The interaction of BAP and NAA treatments on the growth of $\mathrm{A}$. paeoniifolius (JW383) at 4 months after incubation on MS base media

\begin{tabular}{|c|c|c|c|c|c|c|}
\hline \multicolumn{2}{|c|}{$\begin{array}{l}\text { Perlakuan } \\
\text { Treatments }\end{array}$} & \multirow{2}{*}{$\begin{array}{l}\text { Jumlah } \\
\text { Eksplan } \\
\text { Berkalus } \\
\text { Number of } \\
\text { explants to } \\
\text { form callus } \\
(\%)\end{array}$} & \multirow{2}{*}{$\begin{array}{l}\text { Jumlah } \\
\text { Eksplan } \\
\text { Bertunas } \\
\text { Number of } \\
\text { explants to } \\
\text { form shoots } \\
(\%)\end{array}$} & \multirow{2}{*}{$\begin{array}{l}\text { Rata-rata } \\
\text { Jumlah } \\
\text { Tunas } \\
\text { The } \\
\text { average } \\
\text { number } \\
\text { of shoots }\end{array}$} & \multirow{2}{*}{$\begin{array}{l}\text { Jumlah } \\
\text { Eksplan } \\
\text { Berakar } \\
\text { Number of } \\
\text { explants to } \\
\text { form roots } \\
(\%)\end{array}$} & \multirow{2}{*}{$\begin{array}{l}\text { Rata- } \\
\text { rata } \\
\text { Jumlah } \\
\text { Akar } \\
\text { The } \\
\text { average } \\
\text { number } \\
\text { of roots }\end{array}$} \\
\hline $\mathrm{BAP}$ & NAA & & & & & \\
\hline $0 \mathrm{mg} / 1$ & $0 \mathrm{mg} / \mathrm{l}$ & $0,00 \mathrm{~g}$ & $0,00 \mathrm{c}$ & $0,00 \mathrm{c}$ & $0,00 \mathrm{c}$ & $0,00 \mathrm{c}$ \\
\hline $1 \mathrm{mg} / 1$ & $0 \mathrm{mg} / 1$ & $50,00 \mathrm{~d}$ & $16,67 \mathrm{bc}$ & $0.33 \mathrm{bc}$ & $16,67 \mathrm{~b}$ & $0,33 \mathrm{c}$ \\
\hline $1 \mathrm{mg} / 1$ & $0,5 \mathrm{mg} / 1$ & $58,50 \mathrm{c}$ & $6.67 \mathrm{c}$ & $0,07 \mathrm{c}$ & $56,67 \mathrm{a}$ & $6,23 \mathrm{a}$ \\
\hline $2 \mathrm{mg} / 1$ & $0 \mathrm{mg} / 1$ & $25,00 \mathrm{f}$ & $6.67 \mathrm{c}$ & $0,07 \mathrm{c}$ & $6,67 \mathrm{~b}$ & $0,13 \mathrm{c}$ \\
\hline $2 \mathrm{mg} / \mathrm{l}$ & $0,5 \mathrm{mg} / \mathrm{l}$ & $75,00 \mathrm{a}$ & 50,00 a & $1,03 a$ & 56,67 a & $7,57 \mathbf{a}$ \\
\hline $4 \mathrm{mg} / 1$ & $0 \mathrm{mg} / \mathrm{l}$ & $33,33 \mathrm{e}$ & $16,67 \mathrm{bc}$ & 0,17 & $6,67 \mathrm{~b}$ & $0,13 \mathrm{c}$ \\
\hline $4 \mathrm{mg} / 1$ & $0,5 \mathrm{mg} / 1$ & $66,67 \mathrm{~b}$ & $33,33 \mathrm{ab}$ & $0,53 \mathrm{~b}$ & $56,67 \mathrm{a}$ & $3,00 \mathrm{~b}$ \\
\hline KK $(\%)$ & & 20,52 & 40,74 & 37,85 & 35,00 & 34,16 \\
\hline
\end{tabular}

Keterangan: angka - angka yang diikuti huruf yang sama pada perlakuan dan peubah yang sama tidak berbeda nyata pada uji DMRT taraf 5\%. Data jumlah eksplan bertunas diolah dan ditransformasi ke ( $\mathrm{x}+$ $1,5)^{1 / 2}$ dan data rata-rata jumlah tunas diolah dan ditransformasi ke ke $(x+0,5)^{1 / 2}$ KK: Koefisien Keragaman

Note: $\quad$ The numbers followed by the same letter in the same treatment and variables were not significantly different in the 5\% DMRT test. Data on the number of explants to form shoot were processed and transformed into $(x+1.5) 1 / 2$ and data on the average number of shoots were processed and transformed into $(x+0.5) 1 / 2$. KK: Coefficient of Variation

Pada perkembangan selanjutnya, kultur pada media MS dengan penambahan $2 \mathrm{mg} / \mathrm{l} \mathrm{BAP}$ dan $0,5 \mathrm{mg} / 1 \mathrm{NAA}$ tersebut mampu menghasilkan planlet atau bibit tanaman yang telah sempurna lebih cepat dibandingkan pada media perlakuan lainnya (Gambar 1). Sehingga untuk perlakuan kedua digunakan media MS dengan kombinasi BAP dan NAA dengan konsentrasi tersebut.

Hasil pengamatan kultur dari 2 jenis eksplan di kondisi gelap dan terang menunjukkan bahwa eksplan dalam bentuk kalus mampu memberikan respon lebih baik yaitu pada persentase jumlah eksplan berkalus dan rata-rata jumlah tunas 
dibandingkan tangkai daun, baik dalam kondisi gelap maupun terang. Sedangkan pada peubah lainnya seperti jumlah eksplan bertunas, jumlah eksplan berakar dan rata-rata jumlah akar tidak berbeda nyata antar perlakuan gelap dan terang maupun jenis eksplan (Tabel 3, Gambar 2).
Hasil pengamatan terhadap lingkungan mikro di ruang inkubasi menunjukkan suhu di ruang ruang inkubasi berkisar antara 23,5 sampai $25,3^{\circ} \mathrm{C}$. Sedangkan kelembapan di ruang inkubasi berkisar antara $47-51 \%$.
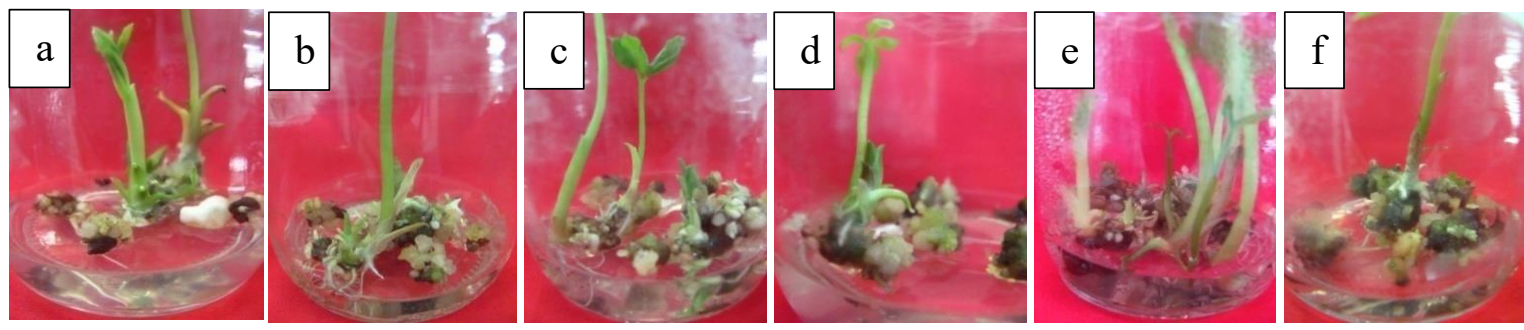

Keterangan:

(a) Media dasar MS ditambahkan $1 \mathrm{mg} / \mathrm{l} \mathrm{BAP}$

(b) Media dasar MS ditambahkan $2 \mathrm{mg} / 1 \mathrm{BAP}$

Noted:

(c) Media dasar MS ditambahkan $4 \mathrm{mg} / \mathrm{l}$ BAP

(a) MS base media added with $1 \mathrm{mg} / \mathrm{l} B A P$

(b) MS base media added with $2 \mathrm{mg} / \mathrm{l} B A P$

(c) MS base media added with $4 \mathrm{mg} / \mathrm{l} B A P$

(d) Media dasar MS ditambahkan $1 \mathrm{mg} / \mathrm{l}$ BAP dan $0.5 \mathrm{mg} / 1 \mathrm{NAA}$

(e) Media dasar MS ditambahkan $2 \mathrm{mg} / \mathrm{l}$ BAP dan $0.5 \mathrm{mg} / 1 \mathrm{NAA}$

(f) Media dasar MS ditambahkan $4 \mathrm{mg} / \mathrm{l} \mathrm{BAP}$ dan $0.5 \mathrm{mg} / 1 \mathrm{NAA}$

(d) MS base media added with $1 \mathrm{mg} / \mathrm{l} B A P$ and 0.5 $m g / l N A A$

(e) MS base media added with $2 \mathrm{mg} / \mathrm{l} B A P$ and 0.5 $m g / l N A A$

(f) MS base media added with $4 \mathrm{mg} / \mathrm{l} B A P$ and 0.5 $m g / l N A A$

Gambar 1. Pertumbuhan kultur A. paeoniifolius (JW383) 8 bulan setelah tanam pada media perlakuan

Figure 1. The growth of A. paeoniifolius (JW383) culture at 8 months after planting on the treatment media

Hasil penelitian ini menunjukkan jumlah tunas yang dihasilkan dari kultur tangkai daun suweg pada berbagai media perlakuan jauh lebih rendah daripada jumlah tunas yang dihasilkan dari kultur tangkai daun Amorphophalus muelleri pada media yang sama (Imelda, 2008). Hasil penelitian mereka menunjukkan ratarata jumlah tunas terbanyak yang dihasilkan dari kultur tangkai daun $A$. muelleri mencapai 19 tunas pada media MS dengan penambahan $2 \mathrm{mg} / \mathrm{l}$ BAP. Tetapi hasil penelitian (Prayana et al., 2017) hanya menghasilkan rerata maksimal 1,08 tunas A. muelleri pada hari ke 63 setelah tanam di media MS dengan penambahan $1 \mathrm{mg} / \mathrm{l}$ BAP dan $0,1 \mathrm{mg} / \mathrm{l}$ NAA. Pada publikasi sebelumnya dilaporkan jumlah tunas kultur $A$. muelleri bisa mencapai 37 tunas pada media MS dengan penambahan $0,2 \mathrm{mg} / 1$ thidiazuron (TDZ) dan $0,5 \mathrm{mg} / 1$ BAP (Imelda et al., 2007). Hasil penelitian ini didukung oleh data penelitian sebelumnya yang mengindikasikan bahwa $A$. muelleri merupakan jenis tanaman yang paling mudah diperbanyak dengan teknik kultur jaringan dibandingkan dengan $A$. paeoniifolius dan $A$. variabilis (Isnaini et al., 2012). 
Tabel 3. Interaksi perlakuan kondisi kultur dan jenis eksplan terhadap pertumbuhan $A$. paeoniifolius (JW383) 5 bulan setelah diinkubasi

Table 3. The interaction of culture condition treatment and type of explant on the growth of A. paeoniifolius (JW383) at 5 months after incubation

\begin{tabular}{|c|c|c|c|c|c|c|}
\hline $\begin{array}{l}\text { Perlakuan } \\
\text { Treatments }\end{array}$ & $\begin{array}{l}\text { Jenis Eksplan } \\
\text { Type of } \\
\text { explant }\end{array}$ & $\begin{array}{l}\text { Jumlah } \\
\text { Eksplan } \\
\text { Berkalus } \\
\text { Number of } \\
\text { explants to } \\
\text { form callus } \\
(\%)\end{array}$ & $\begin{array}{l}\text { Jumlah } \\
\text { Eksplan } \\
\text { Bertunas } \\
\text { Number of } \\
\text { explants to } \\
\text { form shoots } \\
(\%)\end{array}$ & $\begin{array}{l}\text { Rata-rata } \\
\text { Jumlah } \\
\text { Tunas } \\
\text { The } \\
\text { average } \\
\text { number of } \\
\text { shoots }\end{array}$ & $\begin{array}{l}\text { Jumlah } \\
\text { Eksplan } \\
\text { Berakar } \\
\text { Number of } \\
\text { explants to } \\
\text { form roots } \\
(\%)\end{array}$ & $\begin{array}{l}\text { Rata- } \\
\text { rata } \\
\text { Jumlah } \\
\text { Akar } \\
\text { The } \\
\text { average } \\
\text { number } \\
\text { of roots }\end{array}$ \\
\hline $\begin{array}{l}\text { Gelap } \\
\text { Dark }\end{array}$ & $\begin{array}{l}\text { Tangkai Daun } \\
\text { Petiole }\end{array}$ & $30,70 \mathrm{~b}$ & $0,73 \mathrm{a}$ & $0,25 \mathrm{~b}$ & $8,58 \mathrm{a}$ & $1,55 \mathrm{a}$ \\
\hline condition & $\begin{array}{l}\text { Kalus } \\
\text { Callus }\end{array}$ & $100,00 \mathrm{a}$ & $21,43 \mathrm{a}$ & $2,44 \mathrm{a}$ & $16,08 \mathrm{a}$ & $1,50 \mathrm{a}$ \\
\hline $\begin{array}{l}\text { Terang } \\
\text { Light }\end{array}$ & $\begin{array}{l}\text { Tangkai Daun } \\
\text { Petiole }\end{array}$ & $19,30 \mathrm{~b}$ & $1,43 \mathrm{a}$ & $0,25 \mathrm{~b}$ & $5,73 \mathrm{a}$ & $1,20 \mathrm{a}$ \\
\hline condition & $\begin{array}{l}\text { Kalus } \\
\text { Callus }\end{array}$ & $73,20 \mathrm{a}$ & $23,20 \mathrm{a}$ & $1,54 \mathrm{a}$ & $7,13 \mathrm{a}$ & $3,38 \mathrm{a}$ \\
\hline \multicolumn{2}{|c|}{ KK (\%) } & 25,92 & 68,38 & 63,68 & 43,74 & 46,16 \\
\hline
\end{tabular}

Keterangan: angka - angka yang diikuti huruf yang sama pada perlakuan dan peubah yang sama tidak berbeda nyata pada uji DMRT taraf 5\%. Data persentase jumlah eksplan bertunas, persentase jumlah eksplan berakar, dan rata-rata jumlah akar diolah dan ditransformasi ke $(x+1,5)^{1 / 2}$ dan persentase eksplan berkalus diolah dan ditransformasi ke ke $(\mathrm{x}+0,5)^{1 / 2}$. KK: Koefisien Keragaman

Note: $\quad$ The numbers followed by the same letter in the same treatment and variables were not significantly different in the 5\% DMRT test. Data on the number of explants to form shoot, number of explants to form roots and the average number of roots were processed and transformed into $(x+1.5)$ $1 / 2$ and data on number of explants to form callus were processed and transformed into $(x+0.5)$ 1/2. KK: Coefficient of Variation

Secara umum hasil penelitian ini mirip dengan hasil terbaik untuk kultur tangkai daun $A$. albus pada media MS dengan penambahan $2 \mathrm{mg} / \mathrm{l} \mathrm{BA}$ dan 0,5 mg/l NAA (Hu et al., 2006). Pada media tersebut, $71,2 \%$ eksplan membentuk struktur menyerupai umbi (corm like structure) dan $26,7 \%$ dari struktur tersebut berdiferensiasi membentuk tunas. Selanjutnya (Hu et al., 2008) melaporkan hasil terbaik dari kultur tangkai daun $A$. albus adalah pada media MS dengan perbandingan konsentrasi sitokinin: auksin (4:1). Pada perbandingan konsentrasi zat pengatur tumbuh tersebut, sebanyak 70 $78 \%$ dari kalus A. albus mampu membentuk rata-rata 6,4 sampai 7,8 tunas/kalus.
Hasil penelitian lainnya mengindikasikan bahwa penambahan 0,5 $\mathrm{mg} / \mathrm{l}$ NAA pada media MS mampu memacu pertumbuhan akar pada kultur dari mata tunas umbi A. oncophyllus (Amphawan et al., 2001). Di lain pihak, hasil terbaik untuk kultur dari mata tunas umbi A. paeoniifolius (A. campanulatus var hortensis) dihasilkan pada media dengan penambahan $0,1 \mathrm{mg} / 1 \mathrm{NAA}$ dan 0,01 mg/l kinetin (Irawati et al., 1986), sedangkan media terbaik untuk pertumbuhan tunas, akar dan umbi untuk $A$. titanum adalah media MS dengan penambahan $0,3 \mathrm{mg} / \mathrm{l} \mathrm{NAA}$ dan $0,03 \mathrm{mg} / 1$ zeatin (Irawati, 2011).

Hasil penelitian ini mengindikasikan bahwa eksplan berupa kalus mampu memberikan respon lebih baik daripada 
tangkai daun di kondisi gelap maupun terang. Hal ini terlihat dari tingginya jumlah kalus yang menghasilkan tunas dibandingkan dengan tangkai daun baik dalam kondisi gelap maupun terang (Gambar 2). Hasil penelitian (Irawati, 2000) menunjukkan bahwa tunas pucuk merupakan eksplan yang paling baik untuk perbanyakan kerabat Araceae lainnya (Philodendron goeldii) secara in vitro. Sedangkan pada kultur pelepah daun dan daun Caladium hibrida, respon terbaik dijumpai pada bagian pangkal dan ujung dari pelepah daun yang digunakan sebagai sumber eksplan (Irawati, 2005).

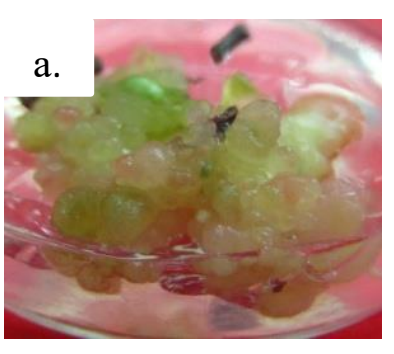

Keterangan:
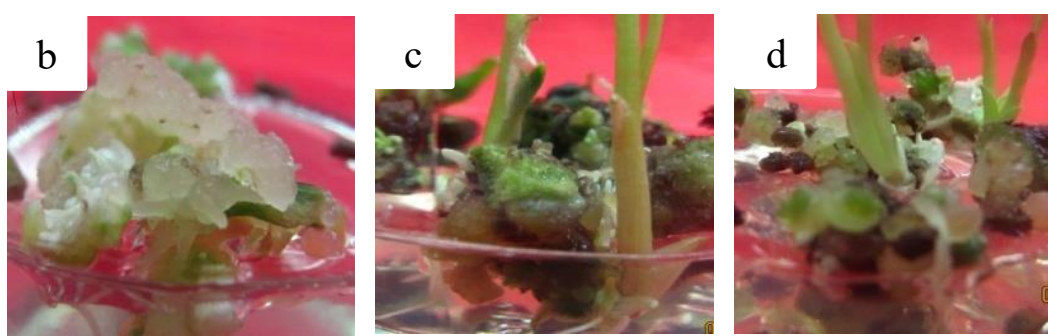

Note:

(a) Eksplan tangkai daun yang diinkubasi pada kondisi terang (a) Petiole explant incubated in light condition

(b) Eksplan tangkai daun yang diinduksi pada kondisi gelap

(b) Petiole explant incubated in dark condition

(c) Eksplan kalus yang diinkubasi pada kondisi terang

(d) Eksplan kalus yang diinkubasi pada kondisi gelap

(c) Callus explant incubated in light condition

(d) Callus explant incubated in dark condition

Gambar 2. Hasil kultur A. paeoniifolius (JW383) pada 5 bulan setelah subkultur dari dua jenis eksplan berbeda pada kondisi gelap dan terang

Figure 2. Result of A. paeoniifolius (JW383) at 5 months after subculture of two different types of explants in dark and light conditions

Pada penelitian ini, tangkai daun yang digunakan dipotong-potong dan ditanam secara acak pada media kultur, sehingga tidak bisa dibedakan bagian mana yang mampu memberikan respon paling baik. Tangkai daun awalnya mengalami pembengkakan di bagian bekas potongan, lalu bagian tersebut merekah membentuk kalus terlebih dahulu. Sedangkan eksplan yang telah berbentuk kalus, beberapa langsung beregenerasi membentuk tunas atau akar setelah ditanam di media dengan penambahan sitokinin BAP dikombinasikan dengan auksin NAA. Hal ini terkait dengan peran auksin untuk merangsang pertumbuhan kalus dan pembentukan akar, serta peran sitokinin untuk memacu pembelahan sel yang dikenal dengan istilah sitokinesis (Lestari, 2011). Kombinasi auksin dan sitokinin dengan perbandingan konsentrasi tertentu dapat mengatur tipe morfogenesis yang dikehendaki.

Peran cahaya dalam penelitian ini tidak terlalu signifikan terhadap pertumbuhan kultur kalus dan tangkai daun suweg yang disimpan pada kondisi gelap dan terang. Hasil yang agak berbeda dilaporkan pada semua kultivar Brassica napus, cahaya berperan memacu pertumbuhan kalus dan menghambat pertumbuhan akar pada kultur hipokotil, tetapi dengan menggunakan bagian kotiledon sebagai sumber eksplan, kondisi gelap lebih mendukung untuk pembentukan kalus (Tavakkol Afshari et al., 2011). Sedangkan (Ali et al., 2012) melaporkan bahwa hasil terbaik untuk kultur Dalbergia sissoo dalam pembentukan tunas adalah pada kultur 
yang diinkubasi pada kondisi terang dengan lama penyinaran $16 \mathrm{jam} / \mathrm{hari}$. Hasil penelitian Chen et al. (2019) pada perbanyakan tanaman Howartia secara in vitro, intensitas cahaya merupakan faktor penting untuk pembentukan kalus dan regenerasi tunas. Kombinasi antara intensitas cahaya dan zat pengatur tumbuh sangat diperlukan untuk meningkatkan pembentukan organ pada komoditi tersebut. Untuk selanjutnya diperlukan optimalisasi kondisi cahaya untuk mendukung budidaya tanaman ini untuk tujuan komersial, konservasi plasma nutfah, atau untuk keperluan penelitian lebih lanjut.

\section{KESIMPULAN}

Media dasar MS dengan penambahan $2 \mathrm{mg} / \mathrm{l}$ BAP dan $0,5 \mathrm{mg} / 1$ NAA merupakan media yang paling mendukung pembentukan tunas dari kultur tangkai daun suweg, tetapi eksplan berupa kalus lebih mudah memberikan respon dibandingkan dengan tangkai daun pada kondisi ruang kultur gelap atau terang.

\section{DAFTAR PUSTAKA}

Ali, A., Rizwan, M., Majid, A., Saleem, A., 㖽 \& Naveed, N. H. (2012). Effect of media type and explants source on micropropagation of Dalbergia sissoo: A tree of medicinal importance. Journal of Medicinal Plants Research, 6(9), 1742-1751. https://doi.org/10.5897/JMPR11.155 1

Amphawan, R., Pookmanee, T., \& 钢 Topoonyanont, N. (2001). Influence of auxin on micropropagation of Amorphophallus oncophyllus prain ex Hook. F. In vitro. Proceeding of the 3rd Maejo University Annual Conference, 567-579.

Bhatia, N., Bozorg, B., Larsson, A., Ohno, 钢 C., Jönsson, H., \& Heisler, M. G.
(2016). Auxin Acts through MONOPTEROS to Regulate Plant Cell Polarity and Pattern Phyllotaxis. Current Biology, 26(23), 3202-3208. https://doi.org/10.1016/j.cub.2016.0 9.044

Chen, C. (2004). Humidity in Plant Tissue EQ Culture Vessels. Biosystems Engineering, 88(2), 231-241. https://doi.org/10.1016/j.biosystems eng.2004.02.007

Chen, Y.-M., Huang, J.-Z., Hou, T.-W., \& E Pan, I.-C. (2019). Effects of light intensity and plant growth regulators on callus proliferation and shoot regeneration in the ornamental succulent Haworthia. Botanical Studies, 60(1), $10 . \quad \mathrm{https}: / /$ doi.org/10.1186/s40529-019-0257-y

Faridah, D. N. (2005). Sifat Fisiko Kimia 暿 Tepung Suweg (Amorphophallus campanulatus B1.) Dan Indeks Glisemiknya. Teknologi Dan Industri Pangan, 16(3), 254-259.

Hasanah, U., Hadi, E. P., \& Hidayah, A. (2014). Keanekaragaman dan Pemanfaatan Ubi-Ubian sebagai Alternatif Tanaman Pangan di Kecamatan Bantarkawung Kabupaten Brebes Diversity and uses of Tubers as Alternative Food Sources in Bantarkawung Brebes Regency. Biosfera, 31(2), 61-70. https://doi.org/10.20884/1.mib.2014. 31.2.215

Hu, J. B., Liu, J., Xie, C. H., \& Gao, X. X. (2006). Corm induction and multiplication of Amorphophallus albus in vitro. The Journal of Horticultural Science and Biotechnology, 81(5), 859-863. https://doi.org/10.1080/14620316.20 06.11512150 
Hu, J. B., Liu, J., Yan, H. B., \& Xie, C. H. (2005). Histological observations of morphogenesis in petiole derived callus of Amorphophallus rivieri Durieu in vitro. Plant Cell Reports, 24(11), 642-648. https://doi.org/ $10.1007 / \mathrm{s} 00299-005-0002-8$

Hu, J., Gao, X., Liu, J., Xie, C., \& Li, J. (2008). Plant regeneration from petiole callus of Amorphophallus albus and analysis of somaclonal variation of regenerated plants by RAPD and ISSR markers. Botanical Studies, 49(3), 189-197.

Imelda, M. (2008). Shoot regeneration 尌 from leaf petioles of iles-iles (Amorphophallus muelleri Blume). Biodiversitas, Journal of Biological Diversity, 9(3), 173-176. https:// doi.org/10.13057/biodiv/d090304

Imelda, M., Wulansari, A., \& Poerba, Y. S. (2007). Mikropropagasi tanaman Iles-iles (Amorphophallus muelleri Blume). Berita Biologi, 8(4), 271277. https://doi.org/10.14203/ beritabiologi.v8i4.2117

Irawati. (2000). Diferensiasi Berbagai Macam Eksplan Pada Perbanyakan Philodendron goeldii ( Araceae ) Secara In-Vitro [ Differentiation of Several Explants on In-vitro Propagation of Philodendron goeldii (Araceae )]. Berita Biologi, 5(April), 69-75. https://doi.org/10.14203/ beritabiologi.v5i1.1100

Irawati. (2005). Pembentukan Kalus dan Embriogenesis Kultur Pelepah Daun dan Daun Caladium Hibrida [ Callus formation and embryogenesis of petiole and leaf cultures of Caladium hybrid ]. Berita Biologi, 7(5), 257261. https://doi.org/10.14203/ beritabiologi.v7i5.876
Irawati. (2011). Micropropagation of A 尌 titanum Becc. (Araceae). Buletin Kebun Raya, 14(1), 29-36.

Irawati, Arditti, J., \& Nyman, L. P. (1986). E In Vitro Propagation of the Elephant Yam, Amorphophallus campanulatus var. hortensis Backer (Araceae). Annals of Botany, 57(1), 11-17. https://doi.org/10.1093/ oxfordjournals.aob.a087088

Isnaini, Y., Wahyuni, S., \& Rahayu, E. M. 毁 Della. (2010). Keberadaan dan Pemanfaatan Umbi Suweg (Amorphophallus paeoniifolius Dennst. Nicolson) di beberapa daerah di Jawa Tengah dan Jawa Timur. Prosiding Seminar Nasional Green Technology, D60-D65.

Isnaini, Y., Wahyuni, S., \& Yuzammi. (2012). Aplikasi Kultur Jaringan untuk Perbanyakan Araceae Berpotensi Pangan. Prosiding Simposium Dan Seminar Bersama PERAGI-PERHORTI-PERIPI-HIGI "Mendukung Kedaulatan Pangan Dan Energi Yang Berkelanjutan," 302-306.

Kamala, S., \& Makeshkumar, T. (2014). Elimization of in vitro regeneration and microcorm induction in elephant foot yam (Amorphophallus paeoniifolius). African Journal of Biotechnology, 13(49), 4508-4514. https://doi.org/10.5897/AJB2014.14 141

Kayal, D., Chatterjee, A., \& Datta, R. (2015). Optimization of conditions for in vitro propagation of elephant foot yam (Amorphophallus paeoniifolius (Dennst.) Nicolson) cv. Gajendra and Bidhan Kusum. Plant Cell Biotechnology and Molecular Biology, 16(1-2), 99-107. 
Laksmitawati, D. R., Marwati, U., \& 尌 Indriani, V. (2019). Pengaruh Fermentasi Umbi Suweg (Amorphophallus campanulatus) Terhadap Kadar Makronutrien Dan Nilai Indeks Glikemik Mencit. Kartika: Jurnal Ilmiah Farmasi, 6(1), 21. https://doi.org/10.26874/ kjif.v6i1.124

Lestari, E. G. (2011). Peranan Zat Pengatur 钢 Tumbuh dalam Perbanyakan Tanaman melalui Kultur Jaringan. Jurnal AgroBiogen, 7(1), 63. https://doi.org/10.21082/jbio.v7n1.2 011.p63-68

Lianah, L., Tyas, D. A., Armanda, D. T., \& 尌 Setyawati, S. M. (2018). Aplikasi Umbi Suweg (Amorphophallus campanulatus) Sebagai Alternatif Penurun Gula Darah Pada Penderita Diabetes Mellitus. Al-Hayat: Journal of Biology and Applied Biology, 1(1), 1. https://doi.org/10.21580/ah.v1i1. 2666

Mutaqin, A. Z., Kurniadie, D., Iskandar, J., 理 Nurzaman, M., \& Partasasmita, R. (2020). Ethnobotany of suweg, Amorphophallus paeoniifolius: Utilization and cultivation in West Java, Indonesia. Biodiversitas Journal of Biological Diversity, 21(4), 1635-1644. https://doi.org/ $10.13057 /$ biodiv/d210444

Nurdyansyah, F., Retnowati, E. I., 钢 Muflihati, I., \& Muliani, R. (2019). Nilai Indeks Glikemik Dan Beban Glikemik Produk Olahan Suweg (Amorphophalus campanulatus BI). Jurnal Teknologi Pangan, 13(1), 7685. https://doi.org/10.33005/jtp. v13i1.1513

Prayana, F. A., Djenal, F., \& Wardana, R. (2017). Mikropropagasi Tangkai
Daun Iles-Iles (Amorphophallus muelleri Blume) Secara In Vitro dengan Penambahan ZPT BAP dan NAA. Agriprima, Journal of Applied Agricultural Sciences, 1(2), 95-104. https://doi.org/10.25047/agriprima.v $1 \mathrm{i} 2.45$

Richana, N., \& Sunarti, T. C. (2004). 钢 Karakterisasi Sifat Fisikokimia Tepung Umbi Dan Tepung Pati Dari Umbi Ganyong, Suweg, Ubikelapa Dan Gembili. J.Pascapanen, 1(1), 29-37. https://doi.org/10.21082/ jpasca.v1n1.2004.29-37

Santosa, E., Mine, Y., Nakata, M., Lian, C., 尌 \& Sugiyama, N. (2010). Genetic diversity of cultivated elephant foot yam (Amorphophallus paeoniifolius) in Kuningan, West Java as revealed by microsatellite markers. Journal of Applied Horticulture, 12(02), 125$128 . \quad$ https://doi.org/10.37855/ jah.2010.v12i02.26

Santosa, E., \& Sugiyama, N. (2016). E Amorphophallus Species in East Nusa Tenggara Islands, Indonesia. Tropical Agriculture and Development, 60(1), 53-57. https://doi.org/10.11248/jsta.60.53

Singh, A., \& Wadhwa, N. (2014). A review on multiple potential of aroid: Amorphophallus paeoniifolius. In International Journal of Pharmaceutical Sciences Review and Research (Vol. 24, Issue 1, pp. 55-60).

Sitorus, E. N., Hastuti, E. D., \& Setiari, N.EQ (2011). Induksi Kalus Binahong (Basella rubra L.) Secara In Vitro Pada Media Murashige \& Skoog Dengan Konsentrasi Sukrosa Yang Berbeda. Induksi Kalus Binahong (Basella Rubra L.) Secara In Vitro 
Pada Media Murashige \& Skoog Dengan Konsentrasi Sukrosa Yang Berbeda, 13(1), 1-7. https:// doi.org/10.14710/bioma.13.1.1-7

Tavakkol Afshari, R., Angoshtari, R., \& 钢 Kalantari, S. (2011). Effects of light and different plant growth regulators on induction of callus growth in rapeseed (Brassica napus L.) genotypes. Plant OMICS, 4(2), 6067.

Witjaksono, Nugraheni, K. U., Hoesen, D. S., \& Irawati. (2012). Perbanyakan Amorphophallus titanumBecc (Araceae) dengan Teknologi In Vitro. Jurnal Biologi Indonesia, $8(2), \quad 343-354 . \quad$ https://doi.org/ 10.14203/jbi.v8i2.3056

Zhao, L. (2012). Embryogenesis and plant 钢 regeneration from unpollinated ovaries of Amorphophallus konjac. African Journal of Biotechnology, 11(70), 13472-13476. https:// doi.org/10.5897/AJB12.1827 